\title{
Metazoan parasites of Mandi-amarelo Pimelodus maculatus and of Jundiá Rhamdia quelen (Osteichthyes: Siluriformes) of Paraíba do Sul River, Volta Redonda, Rio de Janeiro
}

\author{
Metazoários parasitos do Mandi-amarelo Pimelodus maculatus e do Jundiá Rhamdia quelen \\ (Osteichthyes: Siluriformes) do Rio Paraíba do Sul, Volta Redonda, Rio de Janeiro \\ Aline Cristine Pinto Venancio ${ }^{1}$; Gesilene Ribeiro de Aguiar ${ }^{1}$; Patrícia da Silva Lopes ${ }^{1}$; Dimitri Ramos Alves²* \\ ${ }^{1}$ Centro Universitário Geraldo Di Biase - UGB \\ ${ }^{2}$ Curso de Ciências Biológicas, Centro Universitário Geraldo Di Biase - UGB
}

Received February 24, 2010

Accepted April 12, 2010

\begin{abstract}
Forty-one specimens of mandi-amarelo Pimelodus maculatus Lacépède, 1803 (Siluriformes: Pimelodidae) and 54 specimens of jundiá Rhamdia quelen (Quoy \& Gaimard, 1824) (Siluriformes: Heptapteridae) were collected from the Paraíba do Sul River, Volta Redonda, State of Rio de Janeiro, Brazil between November 2007 and October 2008. These fish underwent necropsy so their infracommunities of metazoan parasites could be studied. The same three species of parasites were collected in the two fish species studied. These were one monogenean, one nematode, and one hirudinean. Cucullanus pinnai (Travassos, Artiga, and Pereira, 1928) (Nematoda: Cucullanidae) and Aphanoblastella sp. (Monogenea: Dactylogyridae) were the dominant species with the highest prevalence in $P$. maculatus and $R$. quelen. The parasite species of $P$. maculatus and $R$. quelen showed an atypical over-dispersed pattern of distribution. No parasite species showed significant correlation between the body total length of the siluriform hosts and their prevalence and abundance. The parasite species richness showed a mean value of $0.87 \pm 0.67(0-2)$ and $0.57 \pm 0.56(0-2)$ in P. maculatus and $R$. quelen, respectively, and no correlation with the body total length.
\end{abstract}

Keywords: Pimelodus maculatus, Rhamdia quelen, metazoan parasites, Paraíba do Sul River, Volta Redonda.

\section{Resumo}

Quarenta e um espécimes do mandi-amarelo Pimelodus maculatus Lacépède, 1803 (Siluriformes: Pimelodidae) e 54 espécimes do jundiá Rhamdia quelen (Quoy \& Gaimard, 1824)(Siluriformes: Heptapteridae) foram coletados no Rio Paraíba do Sul, Volta Redonda, Estado do Rio de Janeiro, entre novembro de 2007 e outubro de 2008. Os peixes foram necropsiados para o estudo das suas infracomunidade de metazoários parasitos. Foram coletadas as mesmas três espécies de metazoários parasitos nas duas espécies de peixes estudadas. Estes foram um monogenético, um nematóide e um hirudíneo. Cucullanus pinnai (Travassos, Artiga e Pereira, 1928) (Nematoda: Cucullanidae) e Aphanoblastella sp. (Monogenea: Dactylogyridae) foram as espécies dominantes com os maiores valores de prevalência em $P$. maculatus e $R$. quelen, respectivamente. As espécies de parasitos de $P$. maculatus e $R$. quelen apresentaram típico padrão de distribuição superdispersa. Nenhum parasito apresentou correlação significativa entre o comprimento total dos siluriformes estudados e a prevalência e abundância parasitária. A riqueza parasitária apresentou média de 0,87 $\pm 0,67(0-2)$ e 0,57 $\pm 0,56$ (0 - 2) em P. maculatus e $R$. quelen, respectivamente, e sem correlação com o comprimento total dos hospedeiros.

Palavras-chave: Pimelodus maculatus, Rhamdia quelen, metazoários parasitos, Rio Paraíba do Sul, Volta Redonda.

\footnotetext{
*Corresponding author: Dimitri Ramos Alves

Curso de Ciências Biológicas, Centro Universitário Geraldo Di Biase - UGB,

Rua Deputado Geraldo Di Biase, 81, CEP 27213-080, Aterrado,

Volta Redonda - RJ, Brazil;

e-mail: dimitri_ralves@yahoo.com.br
} 


\section{Introduction}

The Paraíba do Sul River is the main source of lotic waters in the State of Rio de Janeiro. It extends over $1,000 \mathrm{~km}$ and supplies approximately $80 \%$ of the water required by a population of around 12 million people, including millions of inhabitants living in the metropolitan area. The river is also responsible for $20 \%$ of the hydroelectric energy in the state. Its hydrographic basin has an area of approximately $57,000 \mathrm{~km}^{2}$, being mostly flat with its lower-medium area surrounded by rounded hills and small intermediary valleys located at the valley bottoms between the Mar and Mantiqueira ranges (ARAÚJO, 1998; BIZERRIL; PRIMO, 2001; TEIXEIRA et al., 2005). Due to both consumptive and non-consumptive use, the Paraiba do Sul River has suffered a considerable anthropogenic impact (SEMADS, 2001; ARAÚJO et al., 2009). Despite four centuries of exploitation and the fact that the river is located between the two main urban-industrial centers in the country, the river still harbors great biodiversity (ARAÚJO, 1996; 1998; TEIXEIRA et al., $2004 ; 2005)$. A total of 81 species of fish, classified in 9 orders, 29 families, and 55 genera have been found in the river.

The mandi-amarelo Pimelodus maculatus Lacépède, 1803 (Siluriformes: Pimelodidae) is a benthopelagic omnivorous fish with a trend towards being piscivorous. The species is found throughout South America (BIZERRIL; PRIMO, 2001; TEIXEIRA et al., 2005).

The jundiá Rhamdia quelen (Quoy \& Gaimard, 1824) (Siluriformes: Heptapteridae) is a benthonic omnivorous species found in the neotropical region, from Southern Mexico to Argentina. The species has been largely used in pisciculture (GOMES et al., 2000; BIZERRIL; PRIMO, 2001; CARNEIRO; MIKOS, 2005).

The siluriforms here studied are commercially important species that are abundant in the lower-medium region (Volta Redonda) of the Paraíba do Sul River (TEIXEIRA et al., 2005).

A vast literature on $P$. maculatus and $R$. quelen from different regions of Brazil exists. On the parasite fauna of these siluforms, a number of taxonomic studies as well as studies on the occurrence of these species are of great importance. These include the studies by Cellere et al. (2002), Martins et al. (2004), and Matos et al. (2005) on Myxozoa; Kohn (1990), Kritsky et al. (1995, 2000), Brasil-Sato and Pavanelli (2000), Boeger et al. (2001), Cohen and Kohn (2008), and Carvalho et al. (2009) on Monogenea; Kohn and Froes (1986), Kohn et al. (1997), Amato, S. and Amato, J. F. R. (1993), Bello et al. (2000), Brasil-Sato and Pavanelli (2004), Vianna et al. (2005), Kohn et al. (2007), and Silva et al. (2008) on Digenea; Pavanelli and Santos (1992), Rego et al. (1999), and Pertierra (2002) on Cestoda; Brasil-Sato and Pavanelli (1998) and Santos et al. (2008) on Acanthocephala; Travassos et al. (1928), Pinto et al. (1974), Kohn et al. (1985), Kohn and Fernandes (1987), Vicente et al. (1985), Moreira et al. (1991), Thatcher (1991), Moravec et al. (1993a, b), Moravec (1998), Vicente and Pinto (1999), Brasil-Sato (2003), and Madi and Silva (2005) on Nematoda; and Boxshall and Montú (1997), Brasil-Sato et al. (2000), Engers et al. (2000), and Thatcher and Brasil-Sato (2008) on Copepoda. Pereira Junior et al. (2006) have compiled a commented review of the literature on the parasites of Rhamdia in the neotropical region.

Ecological studies of the parasite fauna of $P$. maculatus were done by Brasil-Sato and Pavanelli (1999), and contain data on the acanthocephalus Neoechinorhynchus pimelodi Brasil-Sato and Pavanelli, 1998; by Pavanelli et al. (1997) on endoparasitic helminthes of species of the Paraná River; by Santos et al. (2007) and Albuquerque et al. (2008) on metazoan and endoparasites of the mandi-amarelo from Guandú River, respectively; and by Bachmann et al. (2007) on the parasitic fauna of the P. maculatus from Itajaí-Açu River in Blumenau, Santa Catarina, Brazil.

No studies on the parasite fauna of the fish of Paraíba do Sul River have been done before, although the number of studies on fish parasite biodiversity of the rivers of the State of Rio de Janeiro have increased. Among these are the studies done in the basin of the Guandu River on fish of the Callichthyidae (ABDALLAH et al., 2006, 2007), Characidae (ABDALLAH et al., 2004), Cichlidae (AZEVEDO et al., 2006, 2007; CARVALHO et al., 2008), Curimatidae (ABDALLAH et al., 2005), and Mugilidae (ABDALLAH et al., 2009) families.

Here we present a qualitative and quantitative analysis of the parasite fauna of P. maculatus and R. quelen, of the Paraíba do Sul River, Volta Redonda, Rio de Janeiro, Brazil.

\section{Material and Methods}

A total of 41 species of $P$. maculatus and $R$. quelen underwent necropsy. These fish were obtained by fishermen on the borders of the Paraíba do Sul River, lower-medium region $\left(22^{\circ} 30^{\prime} \mathrm{S}\right.$ and $44^{\circ} 05^{\prime}$ W), in Volta Redonda, Rio de Janeiro, between November 2007 and October 2008. The fish were packed in Styrofoam boxes containing ice to ensure an efficient collection of parasites and protection during transportation to the Laboratory of Biology at Centro Universitário Geraldo Di Biase (UGB). Identification of hosts was done according to Bizerril and Primo (2001) and Reis et al. (2003). The parasites were collected, fixed, and processed according to Eiras et al. (2000).

The $P$. maculatus measured on average $24.6 \pm 3.04(18-31.5) \mathrm{cm}$ of total body length and the $R$. quelen measured on average $23.8 \pm 5.37(16-36)$. The sex of the host was not considered when evaluating the parasitic abundance and prevalence.

Our analysis included only species with prevalence higher than $10 \%$ (BUSH et al., 1990). The frequencies of dominance and of relative dominance (number of individuals of one species/ total number of individuals of all species in each infracommunity) were calculated according to Rohde et al. (1995). The coefficient between variance and mean parasitic abundance (dispersion index, DI) was calculated for each infracommunity, aiming to determine distribution patterns. Its significance was tested using the $d$ statistics (LUDWIG; REYNOLDS, 1988). The ecological terminology used is that indicated by Bush et al. (1997).

Values were considered significant when $\mathrm{p}<0.05$. Data on the length of the host, total number of parasites, and parasitic abundance were transformed into logarithms $(\log x+1)$ for an approximation to the normal distribution (ZAR, 1996). Next, the data were analyzed using the Pearson $(r)$ correlation to check 
for potential correlations with the total length of the host. The Pearson coefficient was also used to investigate the existence of a correlation between the host length and the prevalence of infection/ parasitic infestations, in which previous angle correction of the data on prevalence was done (ZAR, 1996). The host samples were grouped as follows: $P$. maculatus in four intervals with $3.5 \mathrm{~cm}$ of amplitude and $R$. quelen in five intervals of $4 \mathrm{~cm}$ of total body length.

\section{Results}

Of the individuals of $P$. maculatus and $R$. quelen analyzed, 70.8 and $53.0 \%$, respectively, had parasites of at least one species of metazoan. A total of 179 and 292 parasites were collected from $P$. maculatus and $R$. quelen, with an average of $4.3 \pm 5.5$ and $5.4 \pm 9.9$ per host, respectively. Among all the parasite specimens found in both fish specimens, three were common to the two species of fish studied. These parasites were of three types: a monogenean, a nematode, and a hirudinean (Glossiphoniidae). Cucullanus pinnai (Travassos, Artiga and Pereira, 1928) (Nematoda: Cucullanidae) and Aphanoblastella sp. (Monogenea: Dactylogyridae) were the most prevalent and abundant species found in $P$. maculatus and $R$. quelen, respectively (Table 1). In P. maculatus we found $54.7 \%$ monogeneans, $44.8 \%$ nematodes, and $0.5 \%$ hirudineans whereas in $R$. quelen we found $96.3 \%$ monogeneans, $3.4 \%$ nematodes, and $0.3 \%$ hirudineans. The parasite community found in $P$. maculatus showed an atypical over-dispersed distribution pattern with Cucullanus pinnai showing the highest dominance frequency and relative average dominance (Table 2 ). In $R$. quelen the monogenean Aphanoblastella sp. had the highest dominance frequency and relative average dominance and the same over-dispersed pattern (Table 3). No significant correlation was found between the total body length of the host and parasitic abundance and prevalence. The parasite richness of $P$. maculatus and $R$. quelen had mean values of $0.87 \pm 0.67(0-2)$ and $0.57 \pm 0.56(0-2)$, respectively. In both cases the parasite richness did not correlate with parasitic abundance and the total length of $P$. maculatus and $R$. quelen $\left(r_{\mathrm{s}}=-0.020\right.$ and $\mathrm{P}=0.897 ; r_{\mathrm{s}}=0.249$ and $\left.\mathrm{P}=0.068\right)$.

\section{Discussion}

The two species of fish here studied presented the same parasite fauna. However, quantitative differences were observed, with some parasite species dominating more in one fish species than in the other. The fact that both fish species had the same parasites may be explained by the fact that they share biological features, besides the fact that they co-exist geographically. Additionally, both are omnivorous, opportunistic, and scavengers of lagoon and river bottoms (LOWE-McCONNELL, 1999; GOMES et al., 2000; BIZERRIL; PRIMO, 2001; CARNEIRO; MIKOS, 2005; TEIXEIRA; PINTO; ARAÚJO, 2005).

In $P$. maculatus we observed a dominance of the Cucullanus pinnai nematode. This finding agrees with that from studies by Santos et al. (2007) and Albuquerque et al. (2008) in fish from the Guandú River, Rio de Janeiro, Brazil. However, in these studies, the values for parasite prevalence and abundance were higher than the values found in our study. Also relevant is the fact that Albuquerque et al. (2008) found this nematode in the stomach, intestine, and celoma cavity of $P$. maculatus. These authors suggest that $C$. pinnai uses $P$. maculatus as an intermediary and definitive host, with histotrophy and evolutive phases in adults. This idea is supported by the low parasite richness endoparasites of this host in this environment, as compared to other limnic environments, which indicates a low availability of food (ALBUQUERQUE et al., 2008).

In our study we observed a low parasite richness of endoparasites, which were represented only by adult individuals of $C$. pinnai, both in P. maculatus and in $R$. quelen. These nematodes were not obtained from the celloma cavity, which indicates that $P$. maculatus from the Paraíba do Sul River act as definitive hosts only. As for $R$. quelen its piscivirous diet, besides feeding on aquatic invertebrates

Table 1. Metazoan parasites of Pimelodus maculatus and Rhamdia quelen of Paraíba do Sul River, Volta Redonda, Rio de Janeiro.

\begin{tabular}{|c|c|c|c|c|c|c|c|c|c|}
\hline \multirow[t]{2}{*}{ Parasite } & \multicolumn{2}{|c|}{$\begin{array}{l}\text { Prevalence } \\
(\%)\end{array}$} & \multicolumn{2}{|c|}{$\begin{array}{c}\text { Mean } \\
\text { Intensity }\end{array}$} & \multicolumn{2}{|c|}{$\begin{array}{c}\text { Mean } \\
\text { Abundance }\end{array}$} & \multicolumn{2}{|c|}{$\begin{array}{c}\text { Intensity } \\
\text { amplitude }\end{array}$} & \multirow[t]{2}{*}{$\begin{array}{c}\text { Site of } \\
\text { infection }\end{array}$} \\
\hline & $\mathbf{P m}$ & $\mathbf{R q}$ & Pm & $\mathbf{R q}$ & Pm & $\mathbf{R q}$ & $\mathbf{P m}$ & $\mathbf{R q}$ & \\
\hline $\begin{array}{l}\text { Monogean } \\
\text { Aphanoblastella sp. }\end{array}$ & 26.8 & 45 & $8.90 \pm 7.02$ & $11.28 \pm 12.26$ & $2.39 \pm 5.31$ & $5.22 \pm 10.02$ & $1-12$ & $1-41$ & Gills \\
\hline $\begin{array}{l}\text { Nematode } \\
\text { Cucullanus pinnai }\end{array}$ & 58.5 & 11 & $3.33 \pm 2.98$ & $1.8 \pm 1.78$ & $1.95 \pm 2.81$ & $0.16 \pm 0.73$ & $1-20$ & $1-5$ & Intestine \\
\hline $\begin{array}{l}\text { Hirudinean } \\
\text { Unidentified Glossiphonidae }\end{array}$ & 2.4 & 2 & 1 & 1 & $0.024 \pm 0.156$ & $0.018 \pm 0.13$ & 1 & 1 & Gills \\
\hline
\end{tabular}

(Pm)-Pimelodus maculatus; (Rq)-Rhamdia quelen.

Table 2. Dominance and mean relative dominance frequencies, dispersion index (DI), and $d$ statistics of the parasites of Pimelodus maculatus of Paraíba do Sul River, Volta Redonda, Rio de Janeiro.

\begin{tabular}{lcccc}
\hline \multicolumn{1}{c}{ Parasite } & Dominance frequency & Mean relative dominance & DI & $\boldsymbol{d}$ \\
\hline Aphanoblastella sp. & 34.5 & $0.22 \pm 0.39$ & 11.83 & $21.88^{*}$ \\
Cucullanus pinnai & 62 & $0.47 \pm 0.48$ & 4.04 & $9.09^{*}$ \\
Total number of parasites & - & - & 7.14 & $15.02^{*}$ \\
\hline
\end{tabular}

*Significant values $(d>1.96)$. 
Table 3. Dominance and mean relative dominance frequencies, dispersion index (DI), and $d$ statistics of the parasites of Rhamdia quelen of Paraíba do Sul River, Volta Redonda, Rio de Janeiro.

\begin{tabular}{lccrr}
\hline \multicolumn{1}{c}{ Parasite } & Dominance frequency (\%) & Mean relative dominance & DI & d \\
\hline Aphanoblastella sp. & 82.7 & $0.44 \pm 0.49$ & 19.23 & $34.91^{*}$ \\
Cucullanus pinnai & 13.8 & $0.08 \pm 0.26$ & 3.12 & $7.94^{*}$ \\
Total number of parasites & ----- & $-\ldots--$ & 18.34 & $33.84^{*}$ \\
\hline
\end{tabular}

${ }^{*}$ Significant values $(d>1.96)$.

(BIZERRIL; PRIMO, 2001), could explain the existence of phases of histotrophy of $C$. pinnai. However, this was not observed in the present study. Thus, long-term studies on the population dynamics of the nematode-fish interaction are necessary to provide insights on the infection mechanism of this helminth.

The monogenean Aphanoblastella sp. dominated the parasite fauna of $R$. quelen. Carvalho et al. (2009) found increased prevalence (100\%) and mean abundance (71.4 \pm 64.5$)$ of the Aphanoblastella juizforense monogenean in $R$. quelen from Paraibuna River, Minas Gerais, which is considered an ancestor of the Paraíba do Sul River, also known as Alto Paraíba do Sul (SEMADS, 2001).

The over-dispersed distribution pattern has been observed in communities of metazoan parasites of freshwater fish from the southeast of Brazil (ABDALLAH et al., 2004, 2005, 2006; AZEVEDO et al., 2007). However, the dispersion index was not applied in studies with $P$. maculatus (BACHMANN et al., 2007; SANTOS et al., 2007; ALBUQUERQUE et al., 2008), and therefore a comparison with our findings is not possible.

The length of the hosts did not correlate with parasite abundance and prevalence, which agrees with studies done by Bachmann et al. (2007), Santos et al. (2007), and Albuquerque et al. (2008).

The parasite richness found in P. maculatus, in this case comprised by three species only, was lower than that found by Pavanelli et al. (1997). Those authors registered 29 species of parasites in individuals collected in the Rio Paraná. Our results also differ from those described by Bachmann et al. (2007), who found six species of metazoan parasites in individuals collected in the Rio Itajaí-Açu, Blumenau, Santa Catarina, and the results of Santos et al. (2007), who found 10 species of metazoan parasites in $P$. maculatus from Guandú River, Rio de Janeiro.

Another relevant fact on the composition of the parasite fauna described in our study is the lack of digenetic organisms, metacercaria and adults, which were described by other authors (KOHN et al., 1997; PAVANELLI et al., 1997; BRASIL-SATO; PAVANELLI, 2004; BACHMANN et al., 2007; SANTOS et al., 2007). According to Kennedy (1993), the number of parasite species of the infracommunities is considered to be a reflex of the number of host species in the same location and of the capacity of transmitting and infecting intermediary and definitive hosts. Chemical and physical characteristics of the water are limiting and essential factors for the stability of the community of invertebrate aquatic organisms, which may act as intermediary and/or paratenic hosts (SALGADO-MALDONADO; KENNEDY, 1997; MARCOGLIESE, 2001).

The place where $P$. maculatus and $R$. quelen were collected, the lower-medium Paraíba do Sul River in Volta Redonda, is totally urbanized and surrounded by many industries, with constant leakage of toxic products in the water and dumping of industrial and domestic sewers throughout its course (BIZERRIL, 1999; SEMADS, 2001; TEIXEIRA et al. 2004; ARAUJO et al., 2009). This may explain the low parasite richness found in $P$. maculatus and $R$. quelen in this study, as a number of pollutants may affect the fish parasite fauna. These pollutants may act directly on fish, causing immunodepression, which could lead to a higher level of parasites, as described by Madi and Ueta (2009). Or, pollutants may affect parasitism negatively by interfering directly in the larva stages of those with free life, or indirectly by reducing the population of intermediary hosts (POULIN, 1992; ALBUQUERQUE et al., 2008).

\section{References}

ABDALLAH, V. D.; AZEVEDO, R. K.; LUQUE, J. L. Metazoários parasitos dos lambaris Astyanax bimaculatus (Linnaeus, 1758), A. parahybae Eigenmann, 1908 e Oligosarcus hepsetus (Cuvier, 1829) (Osteichthyes: Characidae), do Rio Guandu, Estado do Rio de Janeiro, Brasil. Revista Brasileira de Parasitologia Veterinária, v. 13, n. 2, p. 57-63, 2004.

ABDALLAH, V. D.; AZEVEDO, R. K.; LUQUE, J. L. Ecologia da comunidade de metazoários parasitos do sairú Cyphocharax gilbert (Quoy e Gaimard, 1824) (Characiformes: Curimatidae) do Rio Guandu, Estado do Rio de Janeiro, Brasil. Revista Brasileira de Parasitologia Veterinária, v. 14, n. 4, p. 154-159, 2005.

ABDALLAH, V. D.; AZEVEDO, R. K.; LUQUE, J. L. Ecologia da comunidade de metazoários parasitos do tamboatá Hoplosternum littorale (Hancock, 1828) (Siluriformes: Callichthyidae) do Rio Guandu, Estado do Rio de Janeiro, Brasil. Acta Scientiarum Biological Sciences, v. 28, n. 4, p. 413-419, 2006.

ABDALLAH, V. D.; AZEVEDO, R.K.; LUQUE, J. L. Four new species of Ligophorus (Monogenea: Dactylogyridae) parasitic on Mugil liza (Actinopterygii: Mugilidae) from Guandu River, Southeastern Brazil. Journal of Parasitology, v. 95, n. 4, p. 855-864, 2009.

ABDALLAH, V. D. et al. Two new species of Henneguya Thélohan, 1892 (Myxozoa, Myxobolidae), parasitic on the gills of Hoplosternum littorale (Callichthyidae) and Cyphocharax gilbert (Curimatidae) from the Guandu River, State of Rio de Janeiro, Brazil. Parasitología Latinoamericana, v. 62, p. 35-41, 2007.

ALBUQUERQUE, M. C. et al. Helmintos endoparasitos de Pimelodus maculatus Lacépède, 1803, (Actinopterygii, Pimelodidae) de duas localidades (lagoa e calha do rio) do rio Guandu, Estado do Rio de Janeiro, Brasil. Revista Brasileira de Parasitologia Veterinária, v. 17, supl. 1, p. 113-119, 2008.

AMATO, S.; AMATO, J. F. R. A new species of Phyllodistomum Braun, 1899 (Digenea: Gorgoderidae) from Rhamdia quelen (Quoy e Gaimard, 
1824)(Siluriformes: Pimelodidae). Memórias do Instituto Oswaldo Cruz, v. 88, n. 4, p. 557-559, 1993.

ARAÚJO, F. G. Comunidade e estrutura da comunidade de peixes do médio e baixo Paraíba do Sul River, RJ. Revista Brasileira de Biologia, v. 56, n. 1, p. 111-126, 1996.

ARAÚJO, F. G. Adaptação do índice de integridade biótica usando a comunidade de peixes para o Rio Paraíba do Sul. Revista Brasileira de Biologia, v. 58, n. 4, p. 547-558, 1998.

ARAÚJO, F. G. et al. Distribution of guppies Poecilia reticulata (Peters, 1860) and Phalloceros caudimaculatus (Hensel, 1868) along a polluted stretch of the Paraíba do Sul River, Brazil. Brazilian Journal of Biology, v. 69, n. 1 , p. $41-48,2009$.

AZEVEDO, R. K.; ABDALLAH, V. D.; LUQUE, J. L. Ecologia da comunidade de metazoários parasitos do acará Geophagus brasiliensis (Quoy e Gaimard, 1824) (Perciformes: Cichlidae) do Rio Guandu, Estado do Rio de Janeiro, Brasil. Acta Scientiarum Biological Sciences, v. 28, n. 4, p. 403-411, 2006.

AZEVEDO, R. K.; ABDALLAH, V. D.; LUQUE, J. L. Ecologia da comunidade de metazoários parasitos do apaiarí Astronotus ocellatus (Cope, 1872) (Perciformes: Cichlidae) do Rio Guandu, Estado do Rio de Janeiro, Brasil. Revista Brasileira de Parasitologia Veterinária, v. 16, n. 1, p. 15-20, 2007.

BACHMANN, F. et al. Parasitofauna de Pimelodus maculatus (Osteichthyes: Pimelodidae) do rio Itajaí-Açu em Blumenau, Estado de Santa Catarina, Brasil. Acta Scientiarum Biological Sciences, v. 29, n. 1, p. 109-114, 2007.

BELLO, A. R. R. et al. Lipid peroxidation induced by Clinostomum detruncatum in muscle of the freshwater fish Rhamdia quelen. Diseases of Aquatic Organisms, v. 42, p. 233-236, 2000.

BIZERRIL, C. R. S. F. The icthyofaunaof the Paraíba do Sul River watershed. Biodiversity and biogeografic pateterns. Brazilian Archives of Biology and Tecnology, v. 42, p. 233-250, 1999.

BIZERRIL, C. R. S. F.; PRIMO, P. B. S. Peixes de águas interiores do Estado do Rio de Janeiro. FEEMAR-SEMADS, 2001. 417 p.

BOEGER, W. A.; TANAKA, L. K.; PAVANELLI, G. C. Neotropical Monogenoidea. 39: a new species of Kritskyia (Dactylogyridae, Ancyrocephalinae) from the ureters and urinary bladder of Serrasalmus marginatus and S. spilopleura (Characiformes, Serrasalmidae) from southern Brazil with an emended generic diagnosis. Zoosystema, v. 23, n. 1, p. 5-10, 2001.

BOXSHALL, G. A.; MONTÚ, M. Copepods parasitic on Brazilian coastal fishes: a handbook. Nauplius, v. 5, n. 1, p. 1-225, 1997.

BRASIL-SATO, M. C. Parasitos de peixes da bacia do São Francisco. In: GODINHO, H. P.; GODINHO, A. L. (Org.). Águas, peixes e pescadores do Sáo Francisco das Minas Gerais. Belo Horizonte: Pucminas, 2003. 458 p.

BRASIL-SATO, M. C.; PAVANELLI, G. C. Neoechinorhynchus pimelodisp. n. (Eoacanthocephala, Neoechinorhynchidae) parasitizing Pimelodus maculatus Lacépède, "mandi-amarelo" (Siluroidei, Pimelodidae) from the basin of the São Francisco river, Três Marias, Minas Gerais, Brazil. Revista Brasileira de Zoologia, v. 15, n. 4, p. 1003-1011, 1998.

BRASIL-SATO, M. C.; PAVANELLI, G. C. Ecological and reproductive aspects of Neoechinorhynchus pimelodi Brasil-Sato \& Pavanelli (Eoacanthocephala, Neoechinorhynchidae) of Pimelodus maculatus Lacépède (Siluroidei, Pimelodidae) of the Sao Francisco River, Brazil. Revista Brasileira de Zoologia, v. 16, n. 1, p. 73 - 82, 1999.
BRASIL-SATO, M. C.; PAVANELLI, G. C. Pavanelliella pavanellii Kritsky and Boeger, 1998 (Monogenea: Dactylogyridae) parasito das cavidades nasais de Pimelodus maculatus Lac., 1803, "mandi", das bacias do Rio São Francisco e do Rio Paraná, Brasil. Parasitologia al Dia, v. 24, p. 123-126, 2000.

BRASIL-SATO, M. C.; PAVANELlI, G. C. Digenea de Pimelodus maculatus (Osteichthyes: Pimelodidae) das bacias dos rios São Francisco e Paraná, Brasil. Parasitología Latinoamericana, v. 59, p. 123-131, 2004.

BRASIL-SATO, M. C.; PAVANELLI, G. C.; LUQUE, J. L. Ocorrência e aspectos quantitativos de Gamispinus diabolicus (Copepoda: Ergasilidae) parasitando o mandi-amarelo, Pimelodus maculatus (Siluroidei: Pimelodidae), no Rio Paraná, Brasil. Revista da Universidade Rural, Ciência Vida, v. 22, p. 67-69, 2000.

BUSH, A. O.; AHO, J. M.; KENNEDY, C. R. Ecological versus phylogenetic determinants of helminth parasite community richness. Evolutionary Ecology, v. 4, n. 1, p. 1-20, 1990.

BUSH, A. O. et al. Parasitology meets ecology on its own terms: Margolis et al. revisited. Journal of Parasitology, v. 83, n. 4, p. 575-583, 1997.

CARNEIRO, P. C. F.; MIKOS, J. D. Freqüência alimentar e crescimento de alevinos de jundiá, Rhamdia quelen. Ciência Rural, v. 35, n. 1, p. 187-191, 2005.

CARVALHO, A. R.; TAVARES, L. E. R.; LUQUE, J. L. A new species of Sciadicleithrum (Monogenea, Dactylogyridae) parasitic on Geophagus brasiliensis (Perciformes, Cichlidae) from Guandu River, Southeastern Brazil. Acta Parasitologica, v. 53, p. 237-239, 2008.

CARVALHO, A. R.; TAVARES, L. E. R.; LUQUE, J. L. A new species of Aphanoblastella (Monogenea: Dactylogyridae) parasitic on Rhamdia quelen (Siluriformes: Heptapteridae) from Southeastern Brazil. Acta Scientiarum, v. 31, n. 3, p. 323-325, 2009.

CELlERE, E. F.; CORDEIRO, N. S.; ADRIANO, E. A. Myxobolus absonus sp. n. (Myxozoa: Myxosporea) parasitizing Pimelodus maculatus (Siluriformes: Pimelodidae), a South American freshwater fish. Memórias do Instituto Oswaldo Cruz, v. 97, n. 1, p. 79-80, 2002.

COHEN, S. C.; KOHN, A. New data on species of Demidospermus (Dactylogyridae: Monogenea) parasitizing fishes from the reservoir of the Itaipu Hydroelectric Power Station, Parana State, Brazil, with new synonymies. Revista Brasileira de Parasitologia Veterinária, v. 17, n. 3, p. 167-170, 2008.

EIRAS, J. C.; TAKEMOTO, R. M.; PAVANELLI, G. C. Métodos de estudo e técnicas laboratoriais em parasitologia de peixes. Maringá: Editora Universidade Estadual de Maringá, 2000. 171 p.

ENGERS, K. B.; BOEGER, W. A.; BRANDÃO, D. A. Ergasilus thatcheri n. sp. (Cepepoda, Poecilostomatoida, Ergasilidae) from de gills of Rhamdia quelen (Teleostei, Siluriformes, Pimelodidae) from southern Brazil. Journal of Parasitology, v. 86, p. 945-947, 2000.

GOMES, L. C. et al. Biologia do jundiá Rhamdia quelen (Teleostei, Pimelodidae). Ciência Rural, v. 30, n. 1, p. 179-185, 2000.

KENNEDY, C. R. The dynamics of intestinal helminth communities in eels Anguilla anguilla in a smalll stream: long-term changes in richness and structure. Parasitology, v. 107, n. 1, p. 71-78, 1993.

KOHN, A. Kritskya moraveci n. g., n. sp. (Monogenea:Dactylogyridae) from urinary bladder and uterus of Rhamdia quelen (Quoy \& Gaimard, 1824) (Pisces: Pimelodidae) in Brasil. Systematic Parasitology, v. 17, p. 81-85, 1990. 
KOHN, A.; FERNANDES, B. M. M. Estudo comparativo dos helmintos parasitos de peixes do Rio Mogi Guassu, coletados nas exrcusões realizadas entre 1927 e 1985. Memórias do Instituto Oswaldo Cruz, v. 82, n. 4, p. 483-500, 1987.

KOHN, A.; FERNANDES, B. M. M.; BAPTISTA-FARIAS, M. F. Redescription of Prosthenhystera obesa (Diesing, 1850) (Callodistomidae, Digenea) with new host records and data on morphological variability. Memórias do Instituto Oswaldo Cruz, v. 92, n. 2, p. 171-179, 1997.

KOHN, A.; FERNANDES, B. M. M.; COHEN, S. C. South American trematodes parasites os fishes. Rio de Janeiro: Imprinta Express, 2007. $318 \mathrm{p}$.

$\mathrm{KOHN}$, A. et al. On the Brazilian species of halipegine genera (Trematoda: Derogenidae) from fishes, with new morphological data, hosts and synonyms. Systematic Parasitology, v. 16, p. 201-211, 1990.

$\mathrm{KOHN}$, A. et al. Helminths parasites of freshwater fishes from Pirassununga, SP. Memórias do Instituto Oswaldo Cruz, v. 80, n. 3, p. 327-336, 1985.

KOHN, A.; FROES, O. M. Saccocoelioides godoyi n. sp. (Haploporidae) and other trematodes parasites of fishes from the Guaiba Estuary, RS, Brazil. Memórias do Instituto Oswaldo Cruz, v. 81, n. 1, p. 67-72, 1986.

KRITSKY, D. C.; BOEGER, W. A.; POPAZOGLO, F. Neotropical Monogenoidea. 22. Variation in Scleroductus Species (Gyrodactylidea, Gyrodactylidae) from Siluriform Fishes of Southeastern Brazil. Journal of Helminthology Society of Washington, v. 62, n. 1, p. 53-56, 1995.

KRITSKY, D. C.; MENDOZA-FRANCO, E. F.; SCHOLZ, T. Neotropical Monogenoidea. 36. Dactylogyrids from the Gills of Rhamdia guatemalensis (Siluriformes: Pimelodidae) from cenotes of the Yucatan Peninsula, Mexico, with proposal of Ameloblastella gen. n. and Aphanoblastella gen. n. (Dactylogyridae: Ancyrocephalinae). Comparative Parasitology, v. 67, n. 1, p. 76-84, 2000.

LOWE-McCONNELL, R. H. Estudos ecológicos de comunidades de peixes tropicais. São Paulo: Edusp, 1999. 534 p.

LUDWIG, J. A.; REYNOLDS, J. F. Statistical Ecology: a primer on methods and computing. New York: Wiley-Interscience, 1988. 337 p.

MADI, R. R.; SILVA, M. S. R. Contracaecum, Railliet \& Henry, 1912 (Nematoda, Anisakidae): o parasitismo relacionado à biologia de três espécies de peixes piscívoros no reservatório do Jaguari, SP. Revista Brasileira de Zoociências, v. 7, n. 1, p. 15-24, 2005.

MADI, R. R.; UETA, M. T. O papel de Ancyrocephalinae (Monogenea: Dactylogyridae), parasito de Geophagus brasiliensis (Pisces: Cichlidae), como indicador ambiental. Revista Brasileira de Parasitologia Veterinária, v. 18, n. 2, p. 38-41, 2009.

MARCOGLIESE, D. J. Pursuing parasites up the food chain: Implications of food web structure and function on parasite communities in aquatic systems. Acta Parasitologica, v. 46, n. 2, p. 82-93, 2001.

MARTINS, M. L. et al. Henneguya sp. (Myxozoa: myxobolidae) in Pimelodus maculatus (Osteichthyes: Siluridae) from Volta Grande Reservoir, Minas Gerais, Brazil. Boletim do Instituto de Pesca, v. 30, n. 1, p. 1-7, 2004.

MATOS, E.; TAJDARI, J.; AZEVEDO, C. Ultrastructural studies of Henneguya rhamdia n. sp. (Myxozoa) a parasite from the Amazon teleost fish, Rhamdia quelen (Pimelodidae). Journal of Eukaryotic Microbiology, v. 52, n. 6, p. 532-7, 2005.
MORAVEC, F. Nematodes of freshwater fishes of the neotropical region. Czech Republic, Praha: Academy of Sciences, 1998. 464 p.

MORAVEC, F.; KOHN, A.; FERNANDES, B. M. M. Nematode parasites of fishes of the Paraná river, Brazil. Part 2. Ascaridoidea, Habronematoidea and Acuroidea. Folia Parasitolologica, v. 40, n. 2, p. 115-134, 1993a.

MORAVEC, F.; KOHN, A.; FERNANDES, B. M. M. Nematode parasites of fishes of the Paraná river, Brazil. Part 3. Camallanoidea and Dracunculoidea. Folia Parasitologica, v. 40, n. 2, p. 211-229, 1993 b.

MOREIRA, N. I. B.; OLIVEIRA, C. L.; COSTA, H. M. A. A new helminth parasite os fish: Spirocamallanus freitasi sp. n. (Nematoda: Camallanidae). Memórias do Instituto Oswaldo Cruz, v. 86, n. 4, p. 429-431, 1991.

PAVANELLI, G. C.; SANTOS, M. H. M. Goezeella agostinhoi sp. n. e Monticellia loyolai sp. n., cestóides proteocefalídeos parasitas de peixes pimelodídeos do Rio Paraná, Paraná, Brasil. Revista Brasileira de Parasitologia Veterinária, v. 1, n. 1, p. 45-50, 1992.

PAVANELLI, G. C.; MACHADO, M. H.; TAKEMOTO, R.M. Fauna helmíntica de peixes do rio Paraná, região de Porto Rico, Paraná. In: VAZZOLER, A. E. A. M.; AGOSTINHO, A. A.; HAHN, N. S. (Ed.). A planície de inundaçáo do alto Rio Paraná: aspectos físicos, biológicos e socioeconômicos. Maringá: Eduem, 1997. p. 307-29.

PEREIRA JUNIOR, J.; VIANNA, R. T.; MORAES, N. C. M. Revisão comentada dos parasitos associados a Rhamdia. In: SILVA-SOUZA, A. T. (Ed.). Sanidade de organismos aquáticos no Brasil. Maringá: Abrapoa, 2006. p. 271-295.

PERTIERRA, A. A. G. Redescription of Proteocephalus bagri and P. rhamdiae (Cestoda: Proteocephalidae), Parasites of Rhamdia quelen (Siluriformes: Pimelodidae) from South America, with comments on morphological variation. Folia Parasitologica, v. 49, p. 55-66, 2002.

PINTO, R. M. et al. Procamallanus brasileiros - parte I (Nematoda, Camallanoidea). Memórias do Instituto Oswaldo Cruz, v. 72, n. 3-4, p. 205-211, 1974.

POULIN, R. Toxic pollutinon and parasitism in freshwater fish. Parasitology Today, v. 8, n. 2, p. 58-61, 1992.

REGO, A. A.; CHUBB, J. C.; PAVANELLI, G. C. Cestodes in South American freshwater teleost fishes: keys to genera and brief description of species. Revista Brasileira de Zoologia, v. 16, n. 2, 299-367, 1999.

REIS, R. E.; KULLANDER, S. O.; FERRARIS Jr., C. J. Check list of the freshwater fishes of South and Central America. Porto Alegre: EDIPUCRS, 2003. 742 p.

ROHDE, K.; HAYWARD, C.; HEAP, M. Aspects of the ecology of metazoan ectoparasites of marine fishes. International Journal for Parasitology, v. 25, n. 8, p. 945-970, 1995.

SALGADO-MALDONADO, G.; KENNEDY, C. R. Richness and similarity of helminth communities in the tropical cichlid fish Cichlasoma urophthalmus from the Yucatan Peninsula, Mexico. Parasitology, v. 114, n. 6, p. 581-590, 1997.

SANTOS, C. P. et al. Checklist of Acanthocephala associated with the fishes of Brazil. Zootaxa, v. 1938, p. 1-22, 2008.

SANTOS, M. D.; LEMOS-PITA, S. R. L. C.; BRASIL-SATO, M. C. Metazoan parasite fauna of Pimelodus maculatus La Cépède, 1803 (Siluriformes, Pimelodidae) from the Guandu river, Rio de Janeiro State, Brazil. Acta Scientiarum Biological Sciences, v. 29, n. 1, p. 101-107, 2007. 
SEMADS. Bacias Hidrográficas e Rios Fluminenses: Síntese Informativa por Macrorregião Ambiental. Rio de Janeiro, 2001. 73 p.

SILVA, A. S. et al. Ocorrência de Clinostomum complanatum em diferentes espécies de peixes de uma piscicultura do município de Santa Maria - RS. Veterinária e Zootecnia, v. 15, n. 1, p. 27-32, 2008.

TEIXEIRA, T. P. et al. Distribuição da ictiofauna em locais impactados no rio Paraíba do Sul. Revista Universidade Rural: Série Ciências da Vida, v. 24, n. 2, p. 167-174, 2004.

TEIXEIRA, T.P. et al. Diversidade das assembléias de peixes nas quatro unidades geográficas do rio Paraíba do Sul. Iheringia, v. 95, n. 4 , p. 347-357, 2005.

THATCHER, V. E. Amazon Fish parasites. Manaus: Instituto Nacional de Pesquisas da Amazônia, 1991. 571 p.

THATCHER, V. E.; BRASIL-SATO, M. C. Ergasilus chelangulatus sp. nov. (Copepoda: Ergasilidae) a branchial parasite of the freshwater catfish, Pimelodus maculatus from the upper São Francisco River, Brazil. Revista Brasileira de Zoologia, v. 25, n. 3, p. 512-514, 2008.
TRAVASSOS, L.; ARTIGAS, P.; PEREIRA, C. Fauna helmintológica de peixes de água doce do Brasil. Arquivos do Instituto de Biologia de Sáo Paulo, n. 1, p. 5-68, 1928.

VIANNA, R. T.; PEREIRA JÚNIOR, J.; BRANDÃO, D. A. Clinostomum complanatum (Digenea, Clinostomidae) Density in Rhamdia quelen (Siluriformes, Pimelodidae) from South Brazil. Brazilian Archives of Biology and Technology, v. 48, n. 4, p. 635-642, 2005.

VICENTE, J. J.; PINTO, R. M. Nematóides do Brasil. Nematóides de peixes. Atualização: 1985-1998. Revista Brasileira Zoologia, v. 16, n. 3, p. 561-610, 1999.

VICENTE, J. J.; RODRIGUES, H. O.; GOMES, D. C. Nematóides do Brasil. $1^{a}$ parte: Nematóides de peixes. Atas da Sociedade de Biologia do Rio de Janeiro, v. 25, p. 1-79, 1985.

ZAR, J. H. Biostatistical analysis. $3^{\text {rd }}$ ed. New Jersey: Prentice-Hall, 1996. 662 p. 